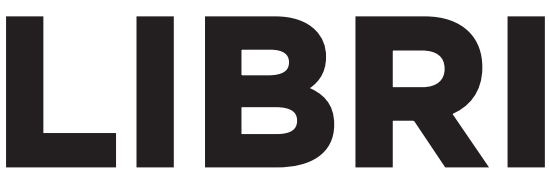

INTERNATIONAL JOURNAL OF LIBRARIES AND INFORMATION STUDIES

\title{
EDITORS
}

Kendra S. Albright, Kent, OH, US

Theo J. D. Bothma, Pretoria, South Africa

\section{ADVISORY EDITORS}

Jamshid Beheshti, Montreal, Canada

Dania Bilal, Knoxville, TN, US

Jenny Bronstein, Tel Aviv, Israel

Nadia Caidi, Toronto, Canada

Elias Sanz Casado, Getafe, Spain

Clara Chu, Illinois, US

Michèle Cloonan, Boston, Massachusetts, US

Dan Dorner, Wellington, New Zealand

Irakli Garibashvili, Tbilisi, Georgia

John Gathegi, Tampa, FL, US

Karen Gavigan, Columbia, South Carolina, US

Lisa Given, Wagga Wagga, Australia

Carl Gustav Johannsen, Copenhagen, Denmark

Isto Huvila, Uppsala, Sweden

Dick Kawooya, Columbia, SC, US

Jinmook Kim, Yongin, Korea

James LaRue, Chicago, Illinois, US

Guoqiu Li, Shanghai, China

Ana Maria Talavera-Ibarra, San Miguel, Peru

Filiberto Felipe Martínez Arellano, Mexico City, Mexico

Constant Okello Obura, Kampala, Uganda

Tony Olden, London, UK

Hermann Roesch, Cologne, Germany

Abebe Rorissa, Albany, New York, US

Irina Trushina, Saint-Petersburg, Russia

Anna Maria Tammaro, Parma, Italy

Ana Vasconcelos, Sheffield, UK

Yin Zhang, Kent, Ohio, US

Lihong Zhou, Wuhan, China

Sandy Zinn, Bellville, South Africa 
ABSTRACTED/INDEXED IN Baidu Scholar · Cabell's Directory · CABI (over 50 subsections) · CNKI Scholar (China National Knowledge Infrastructure) · CNPIEC · Dimensions · EBSCO (relevant databases) · EBSCO Discovery Service · Gale/Cengage · Genamics JournalSeek · Google Scholar · IBR (International Bibliography of Reviews of Scholarly Literature in the Humanities and Social Sciences) · IBZ (International Bibliography of Periodical Literature in the Humanities and Social Sciences) · ICAP Alcohol Information Databases · Japan Science and Technology Agency (JST) · J-Gate · Journal Citation Reports/Social Sciences Edition · JournalGuide $\cdot$ JournalTOCs · KESLI-NDSL (Korean National Discovery for Science Leaders) · Microsoft Academic · MLA International Bibliography $\cdot$ Naviga (Softweco) · Norwegian Register for Scientific Journals, Series and Publishers $\cdot$ Primo Central (ExLibris) · ProQuest (relevant databases) $\cdot$ Publons $\cdot$ ReadCube $\cdot$ SCImago (SJR) $\cdot$ SCOPUS $\cdot$ Sherpa/RoMEO · Summon (Serials Solutions/ProQuest) · TDNet · Ulrich's Periodicals Directory/ulrichsweb · WanFang Data · Web of Science: Current Contents/Social and Behavioral Sciences; Social Sciences Citation Index · WorldCat (OCLC)

The publisher, together with the authors and editors, has taken great pains to ensure that all information presented in this work (programs, applications, amounts, dosages, etc.) reflects the standard of knowledge at the time of publication. Despite careful manuscript preparation and proof correction, errors can nevertheless occur. Authors, editors and publisher disclaim all responsibility and for any errors or omissions or liability for the results obtained from use of the information, or parts thereof, contained in this work.

The citation of registered names, trade names, trademarks, etc. in this work does not imply, even in the absence of a specific statement, that such names are exempt from laws and regulations protecting trademarks etc. and therefore free for general use.

ISSN 0024-2667 · e-ISSN 1865-8423

All information regarding notes for contributors, subscriptions, open access, back volumes and orders are available online at www.degruyter.com/libri.

OPEN ACCESS De Gruyter offers authors the following options to publish their journal article open access:

Gold OA Publishing: Articles are made available immediately OA over the publisher's website.

For terms and conditions see: http://www.degruyter.com/dg/page/583/de-gruyter-open-library

Green OA Publishing: Authors may self-archive the publisher's PDF version of the article for free public use in their institutional repository after an embargo period of twelve months. For terms and conditions see: http://www.degruyter.com/dg/page/576/repository-policy.

RESPONSIBLE EDITORS Kendra S. Albright, Director, School of Library and Information Science, Kent State University, P.O. Box 5190, 314 University Library, 1125 Risman Drive, Kent, OH 44242-0001, USA, Email: kalbrig7@ kent.edu Theo J. D. Bothma, Professor and Head of the Department of Information Science, University of Pretoria, Private Bag X20, 0028 Hatfield, South Africa,

Tel.: +27 (0)12 420-2961, Fax: +27 (0)12 362-5181, Email theo.bothma@up.ac.za

JOURNAL MANAGER Hamizah Adenan, Walter de Gruyter GmbH, Genthiner Str. 13, 10785 Berlin, Germany,

Tel. +49 (0)30 260 05-385, Fax: +49 (0)30 260 05-250, E-mail: hamizah.adenan@ gmail.com

RESPONSIBLE FOR ADVERTISING Claudia Neumann, De Gruyter, Genthiner Straße 13, 10785 Berlin, Germany, Tel.: +49 (0)30 260 05-226, Fax: +49 (0)30 260 05-264, Email: anzeigen@ degruyter.com

(C) 2018 Walter de Gruyter GmbH, Berlin/Boston

TYPESETTING Integra Software Services Pvt. Ltd., Pondicherry, India

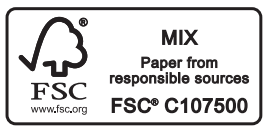




\section{Contents}

\section{Articles}

Michael M. Widdersheim

A Political Theory of Public Library Development

$-269$

Jane Cho

The Trends of Media Coverage about Libraries in Korea:

Using Semantic Network Analysis of Portal

News — 291

Murtaza Ashiq, Shafiq Ur Rehman and Syeda Hina Batool Academic Library Leaders' Challenges, Difficulties and Skills: An Analysis of Common Experiences — 301

Péter Kiszl, Rita Radó and Miklós Péter Hubay From Divergence to Convergence in Hungarian Librarianship: Towards a Common Digital

Platform - 315
Glynnis Johnson and Jaya Raju Knowledge and Skills Competencies for Humanities Librarians Supporting Postgraduate Students — 331

Vicki Lawal, Peter G Underwood and Christine Stilwell Legal Information and the Social Media: Some Current Issues - 345

\section{Miscellaneous}

Best Student Research Paper Award $2019-361$ 